\title{
Portfolio optimization by applying Markov chains
}

\author{
Оптимизација портфолија применом Марковљевих \\ ланаца \\ Нина Петковић ${ }^{*}$ \\ Мегатренд универзитет, Факултет за менаџмент, Зајечар \\ Милан Божиновић ${ }^{*}$ \\ Универзитет у Приштини, Економски фракултет, Косовска Митровица \\ Сања Стојановић ${ }^{* * *}$ \\ Мегатренд универзитет, Факултет за менаџмент, Зајечар
}

Abstract: Since one of the main problems in today's economy is 'conquering the market' or, in other words, finding the best way to predict price movements and receive expected rates of return, this paper will deal with the portfolio optimization in the Belgrade stock exchange. The Markov chains method is chosen as a very simple and non-parametric method which has been insufficiently used and studied in our literature so far. The rare research done in this area usually uses the Harry Markowitz model while the Markov chains method has been applied worldwide in the analyses of financial markets regardless of the degree of their development. Therefore, this paper will be unique as it will be the first to employ the Markov chains method in the returns analysis on the Belgrade Stock Exchange.

Keywords: Markov chains, Belgrade Stock Exchange, portfolio, financial markets, returns.

Сажетак: С'обзиром на то да је један од основних проблема савремене економије „победити тржиште“, тj. предвидети кретање цена и приноса различитих акција, у овом раду се бавимо оптимизацијом портфолија на Београдској берзи. Изабрана је метода Марковљевих ланаца као врло једноставна, непараметарска метода, а у нашој литератури недовољно проучена и искоришћена. У истаживањима која су спроведена у овом подручју углавном је примењена Markowitz-ева метода, док су у истраживањима у свету вршене анализе на финансијском тржишту, применом методе Марковљевих ланаца, без обзира на то колико је развијено. Стога у овом раду, први пут у домаћој литератури, примењујемо Марковљеве ланце за анализу приноса акција на Београдској берзи.

Кључне речи: Марковљеви ланци, Београдска берза, портфолио, финансијско тржиште, приноси

\section{Introduction}

One of the main characteristics of the modern financial market is that it urges every investor to fight for his or her survival in the market no matter if they act alone or as a group or investors. The main goal, in this way, is making as much profit as possible either through buying and selling or owning certain portfolios (a collection of

\footnotetext{
* $₫$ nina.petkovic@fmz.edu.rs

** $\bowtie$ milan_bozinovic@yahoo.com

*** $\bowtie$ sanja.stojanovi@fmz.edu.rs
} 
investments held by an individual or institution, such as stocks, bonds, etc.). At first, this may seem to be an easy way to make money. However, any ill-considered decision may lead to a loss. Before anyone decides to invest in shares, he or she must become acquainted with the market conditions in detail, has to learn about price movements, how the trading is done and how the company in question is developing. Besides, no matter how thoroughly all situations are analyzed, one has to be aware that some level of risk always exists.

If an investor can afford to invest a larger sum of money in different companies, the possibility for making a loss decreases. This is so because if the shares of one company are declining in price, the share price of the other company in which the investor has invested is increasing. Therefore, a higher risk may lead to higher expected returns. If a long-term investment is in question, then the investment is likely to result in even greater profits.

However, considering the amount of capital at their disposal, the investors find it most appealing to invest in safe companies as their business operations are run smoothly and successfully especially over shorter periods of time. It seems that these are the cases of low-risk investments that will make a certain profit during a particular period of time.

What often happens in practice is that different investors pool their resources and invest in a number of different companies, trade with different shares that pay different dividends thus reducing the risk of investment, while at the same time each investor's profit is in proportion to the amount he or she has invested.

In any case, whether we speak of a single investor, a group of investors or a company, besides making precise market forecasts, it is essential to be aware of how the prices move in the market and how the companies do business in this market. Indeed, the saying 'The art of managing is in foreseeing' proves to be true in practice. And it is in the organised and regulated financial market called the stock exchange that this trade takes place.

Harry Markowitz, an American economist laid the foundation of modern portfolio theory, and dealt with the problem of making the maximum expected returns while showing investors how to reduce their risk. His method has also been the most used one in portfolio analyses both in our country and in the world. Recently, the Markov Chains method has become much more interesting to investors when making decisions where to invest. This new non-parametric method is less complex and the results it gives are similar to those obtained by the Markowitz model but faster and easier to gain. 


\section{The Markov chains method}

This chapter will give a description of the essence of the Markov chains method which will be used in our further research. In the area of finance and returns forecasts, this theory was first used by McQueen and Thorley in their essay (McQueen \& Thorley, 1991), then by Doubleday and Esunge in (Doubleday \& Esunge, 2011) who studied the developed American market. There are also papers dealing with the undeveloped Nigerian market (Agwuegbo, Adewole, \& Maduegbuna., 2010), the Prague Stock Exchange (Svoboda \& Lukáš, 2012) and the Zagreb Stock Exchange (Шкрињарић \& Којић, 2014; Шкрињарић \& Шостарић, 2014 ). All these authors analyzed different stock markets at different periods, considered different numbers of companies whose portfolios are interesting and relevant to the stock exchange operations. However, they have one thing in common and that is the following: the returns received by share price changes can be classified into several categories that share common characteristics. These are mostly returns that increase, decrease or remain steady, and the Markov chains method is used as a means of analysis.

In a way, this method is a synthesis of probability theory and matrix multiplication and is especially suitable for cases where certian processes are to be observed but cannot be explained by unique functions containing certian perametres with clearly set conditions. Unfortunately, just as in practice or in nature generally, there are no ideal conditions in economics either where data could be mathematically studied andprocessed to give concrete results. Thus, we have to use non-parametric methods whereby it is not possible to predict the results precisely but with certain probability. The term we have to introduce here is a stochastic process which can be defined as a time sequence representing the evolution of some system represented by a variable whose change is subject to a random variation, and a Markov chain is a special case of discrete stochastic process, that is, it describes systems whose states change over time and form countable state space.

The Markov chain method is named after the Russian mathematician Andrey Markov, who was a pioneer in this area of science. A stochastic process that satisfies the Markov property is called a Markov chain. This property is usually characterized as 'memorylessness' or, in other words, what matters in predicting the future of the system is its present state, and not the path by which the system got to its present state. Now, before dealing with our research in more detail, let us briefly explain the basic elements of this method.

If $X_{0}, X_{1}, \ldots X_{t}, \ldots$ is a sequence of random variables and our prediction is that they belong to a discrete (countable) set of states, we will have the following notation: $S=\left\{x_{1}, x_{2}, \ldots x_{n}\right\}$.

The sequence $\left\{X_{t}\right\}$ is a Markov chain (Божиновић \& Стојановић, 2005) if predicting the future of the system is based on its present state, and not on the past state 


$$
P\left(X_{t}=x_{j} \mid X_{t_{r}}=x_{j_{r}}, \ldots X_{t_{1}}=x_{t_{1}}\right)=P\left(X_{t}=x_{j} \mid X_{t_{r}}=x_{j_{r}}\right)
$$

The time index is $t>t_{\mathrm{r}}>t_{\mathrm{r}-1}>\ldots>t_{1}$ and probability distribution is defined as $\left\{x_{j}, x_{j_{r}}, \ldots, x_{j_{1}}\right\} \subseteq S$.

Transition probability is denoted by $p_{i j}(t)$ meaning that the process starts in state $x_{i}$ and moves to state $x_{j}$ and each move called a step, takes a certain amount of time $t$.

A square matrix of order $n$ containing all transition probabilities is called the matrix of transition probabilities or the transition matrix and is as follows:

$$
P_{t}=\left[\begin{array}{cccc}
p_{11}(t) & p_{12}(t) & \cdots & p_{1 n}(t) \\
p_{21}(t) & p_{22}(t) & \cdots & p_{2 n}(t) \\
\vdots & \vdots & & \vdots \\
p_{n 1}(t) & p_{n 2}(t) & \cdots & p_{n n}(t)
\end{array}\right]=\left[p_{i j}(t)\right]
$$

Every element of the transition matrix can be found in the interval $[0,1]$ considering the following: $\sum_{j=1}^{n} p_{i j}(t)=1$.

For every matrix $P_{t}$ the following is true:

$$
P_{t}=P \cdot P_{t-1}
$$

If $p_{i}(t)=P\left(X_{t}=x_{i}\right)$ denotes the probability of a system at a specific time $t$ and in a specific state $x_{i}$, then we can define the state vector as the vector containing all probabilities of the system being in a specific state at a specific time $t$ or:

$$
\begin{gathered}
s(t)=\left[\begin{array}{cccc}
p_{1}(t) & p_{2}(t) & \cdots & p_{n}(t)
\end{array}\right], \text { and } \\
s(t)=s(t-1) \cdot P
\end{gathered}
$$

By recursion we get the following:

$$
s(t)=s(0) \cdot P^{t}, t \geq 1
$$

whereby $s(0)=\left[\begin{array}{llll}p_{1} & p_{2} & \cdots & p_{n}\end{array}\right]$ denotes the state vector when the system is at the initial time period $t=0$, and $p_{i}=p_{i}(0)=P\left(X_{0}=x_{i}\right)$. Vector $s(0)$ is called the steady (initial) state vector.

A special case is the stationary distribution of a Markov chain (Barnett, Ziegler, \& Byleen, 2006) where the state vector does not depend on the observed time period. In this case the vector is called a stationary distribution or invariant measure. Here if $t \geq 0$, we will have the following: $s(t)=\left[\begin{array}{llll}p_{1} & p_{2} & \cdots & p_{n}\end{array}\right]$.

And after the equation (4) is applied to the stationary distribution, we obtain: 


$$
s=s \cdot P
$$

Unfortunately, the condition for stationarity is not always satisfied in practice, but one of the most significant results of this theory is that a Markov chain possesses a limiting probability distribution thus satisfying the condition (6). Next, with no further proof, we will state the Markov chain theorem (Basharin, Langville, \& Naumov, 2004):

Theorem: For every Markov chain with an infinite state space $x_{1}, x_{2}, \ldots x_{n}$, there are limiting probability distributions $p_{i}^{*}=\lim _{t \rightarrow \infty} p_{i}(t), i=1,2, \ldots n$, that is, the limiting probability distribution vector $s^{*}=\lim _{t \rightarrow \infty} s(t)$.

The limiting probabilities of the state space $p_{i}^{*}$ are called ergodic probabilities, while the limiting probability vector $S^{*}$ is called the ergodic steady state vector:

$$
s^{*}=\left[\begin{array}{llll}
p_{1}^{*} & p_{2}^{*} & \cdots & p_{n}^{*}
\end{array}\right] .
$$

Now the relevant equations (6) will have the following form:

$$
s^{*}=s^{*} \cdot P \Leftrightarrow s^{*} \cdot(I-P)=0
$$

Considering these so-called ergodic equations as well as the condition $\sum_{i=1}^{n} p_{i}^{*}=1$, we can define the wanted ergodic probabilities $p_{i}^{*}$.

The application of this method enables us to define the probabilities whether a system can be found in a particular state or not. Since its usage is relatively simple, it has beeen applied as a research method in different areas and led to some interesting data in medicine, genetics, psychology, politics and economics.

The rest of the paper will deal with the application of Markov chains to the Belgrade stock exchange.

\section{Applying the Markov chains method on the Belgrade Stock Exange}

The data we used were gathered on the Belgrade Stock Exchange for the year 2015. Ten companies were selected and their share prices observed in the period from December 31, 2014 to December 31, 2015. (BELEX, 2014). In this way we analyzed every company using 252 market values. BELEX index was used to monitor the share prices, Excel and MATLAB were used for data processing.

The following table (Table 1) lists the companies' acronyms as well as the full names of the companies we used in our research. 
Table 1: Overview of companies used in the research

\begin{tabular}{||l|l||}
\hline \multicolumn{1}{|c|}{ Company acronym } & \multicolumn{1}{c|}{ Full name of a company } \\
\hline \hline NIS & $\begin{array}{l}\text { Naftna industrija Srbije, joint-stock company, Novi Sad } \\
\text { (Petroleum Industry of Serbia) }\end{array}$ \\
\hline FITO & Galenika Fitofarmacija, joint-stock company, Zemun \\
\hline GMON & Goša Montaža, joint-stock company, Velika Plana \\
\hline AERO & Nikola Tesla Airport, joint-stock company, Belgrade \\
\hline KMBN & Komercijalna Banka, joint-stock company, Belgrade \\
\hline VZAS & $\begin{array}{l}\text { Veterinarski zavod Subotica, joint-stock company, Suboti- } \\
\text { ca (Veterinary Institute) }\end{array}$ \\
\hline IMLK & Imlek, joint-stock company, Belgrade \\
\hline IMPL & Impol Seval, joint-stock company, Sevojno \\
\hline BMBI & Bambi, joint-stock company, Požarevac \\
\hline MTLC & Metalac, joint-stock company, Gornji Milanovac \\
\hline
\end{tabular}

According to data from the stock exchange which quote the share price on a particular day, we can calculate the returns $r_{i}(t)$ for each of the above given companies using the following formula:

$$
r_{i}(t)=\ln \frac{P_{i}(t)}{P_{i}(t-1)}
$$

whereby $P_{i}(t)$ denotes the share price at the time $t, t \in\{1,2, \ldots, 252\}$ for every company $i \in\{1,2, \ldots, 10\}$. When all the data were gathered, 2520 in total, we tried to distribute the data into several states so that we could use Markov chains and analyze them. Our objective in analyzing the data was to gather the information relevant to investors what company to invest in? The analysis of expected returns obtained by change in share prices in the Belgrade stock exchange shows that there are no significant changes and that all expected returns could be classified into three categories each of which displaying certain common characteristics.

Let us assume that $S_{1}$ denotes the state of returns lower than $-0.5 \%$ and $S_{2}$ the returns in the interval $[-0.5 \%, 0.5 \%]$ obtained when the share prices at a given point in time do not differ significantly from the share price at some point in the past. $S_{3}$ denotes the returns higher than $0.5 \%$.

For each company it is necessary to define the returns level for each of these states, after which we can determine the probability of shares that can be found in specific states. These probabilities are in fact relative frequencies calculated as a proportion between the expected returns found in the state $S_{1}, S_{2}$ or $S_{3}$ and the general number of returns, which in our case is 252 .

The following table (Table 2) contains the data regarding the number of returns 
for each state $S_{1}, S_{2}, S_{3}$ with respect to every company whose shares we studied. These data are shown in Picture 1.

Table 2: Distribution of returns and of initial vector values

\begin{tabular}{|c||c|c|c||c|c|c|}
\hline & $S_{1}$ & $S_{2}$ & $S_{3}$ & \multicolumn{3}{|c|}{ Vector $s(0)$} \\
\hline NIS & 64 & 129 & 59 & 0.253968 & 0.511905 & 0.234127 \\
\hline FITO & 40 & 156 & 56 & 0.158730 & 0.619048 & 0.222222 \\
\hline GMON & 25 & 200 & 27 & 0.099206 & 0.793651 & 0.107143 \\
\hline AERO & 81 & 89 & 82 & 0.321429 & 0.353175 & 0.325397 \\
\hline KMBN & 64 & 146 & 42 & 0.253968 & 0.579365 & 0.166667 \\
\hline VZAS & 27 & 204 & 21 & 0.107143 & 0.809524 & 0.083333 \\
\hline IMLK & 36 & 189 & 27 & 0.142857 & 0.75 & 0.107143 \\
\hline IMPL & 28 & 198 & 26 & 0.111111 & 0.785714 & 0.103175 \\
\hline BMBI & 13 & 232 & 7 & 0.051587 & 0.920635 & 0.027778 \\
\hline MTLC & 33 & 185 & 34 & 0.130952 & 0.734127 & 0.134921 \\
\hline
\end{tabular}

Picture 1: Distribution of returns

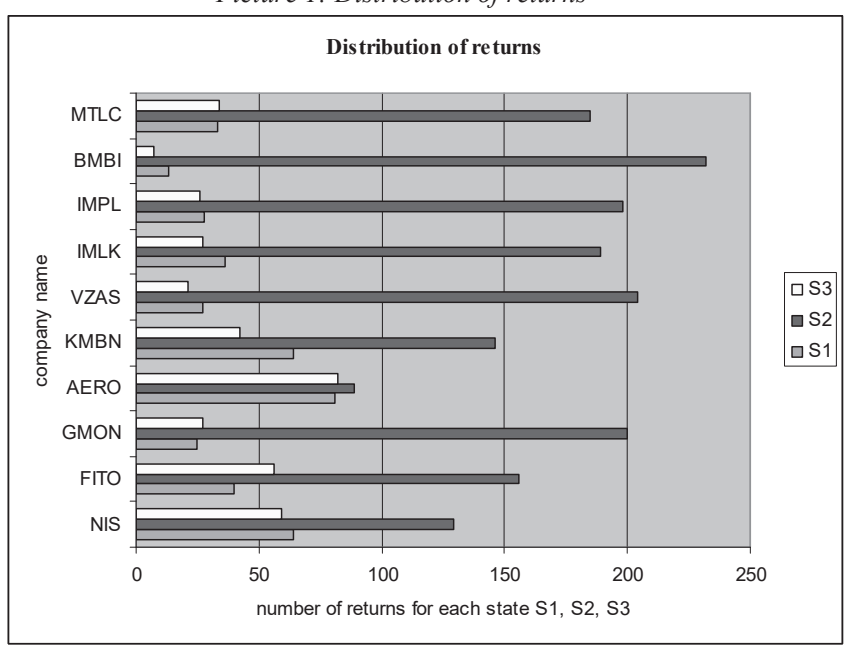

Source: Author

There are also probability distribution values of returns in one of the analyzed states, which are basically vector values $s(0)$, calculated using the aforementioned theory. Each of the probabilities $p_{i,}, i \in\{1,2,3\}, k \in\{1, \ldots, 10\}$ is obtained by formula:

$$
p_{i_{k}}=\frac{f_{i}}{\sum_{i=1}^{3} f_{i}},
$$


whereby $f_{i}$ denotes number of returns found in state $S_{i}, i=1,2,3$, and $\sum_{i=1}^{3} f_{i}=252$.

We will explain the significance of the vector $s(0)$, using the example of the NIS Company, where we get the following results: $s(0)=\left[\begin{array}{llll}0.253968 & 0.511905 & 0.234127\end{array}\right]$.

The interpretation of this vector is as follows: the return of the NIS Company is lower than $-0.5 \%$ with the probability of 0.253968 , while the probability of 0.511905 is to be found in the interval $[-0,5 \% ; 0,5 \%]$, and when the probability is 0.234127 the return is higher than $0.5 \%$. Exactly the same procedure is used in the interpretation of all other values of the vector $s(0)$ for other companies.

Now we will apply Markov chains to the shares of the NIS Company, and this is also done for other companies in the same manner later. The matrix containing the number of state transitions in this case is as follows:

$$
S=\left[\begin{array}{ccc}
26 & 25 & 13 \\
28 & 79 & 22 \\
9 & 26 & 24
\end{array}\right]
$$

Every element $s_{i j}$ shows the number of returns which moves from state $i$ into state $j$. Diagonally, there is a number of returns which remains in the same state. Based on these data we get to the transition matrix $P$, which contains transition probabilities which are again relative frequencies, that is, element $p_{i j}$ is the proportion between the number of transitions from state $i$ to state $j$ and the total number of returns into state $i$. The transition matrix $P$ for the NIS company is the following:

$$
P=\left[\begin{array}{ccc}
0.40625 & 0.390625 & 0.203125 \\
0.217054 & 0.612403 & 0.170543 \\
0.152542 & 0.440678 & 0.40678
\end{array}\right]
$$

On the basis of transition matrix, transition diagram (Picture 2) represents transiton between three states $S_{1}, S_{2}$ or $S_{3}$, where the transitions probabilities between the states are also included.

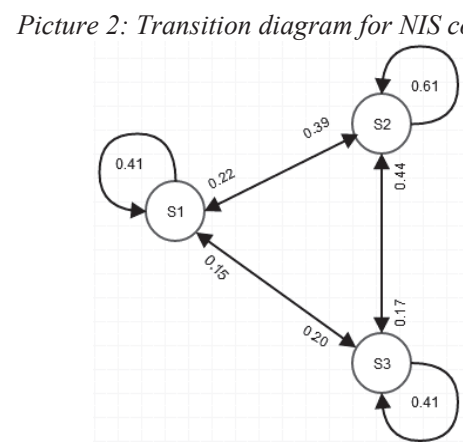

Source: Author 
It is clear that the row sums are 1 . The same procedure is used for other transition matrices. Considering what has been stated in (5), we can now measure the vector $s(1)$ in the first next period as $s(1)=s(0) \cdot P$ and get: $s(1)=\left[\begin{array}{lll}0.25 & 0.515873 & 0.234127\end{array}\right]$.

The ergodic vector $s^{*}$, that is, the ergodic probabilities are found using the equation (7). For the first company we analyzed this vector is as follows:

$$
s^{*}=\left[\begin{array}{lll}
0.2491 & 0.5170 & 0.2339
\end{array}\right]
$$

It shows that there is 0.2491 probability that the expected return in shares of the NIS Company will be lower than $-0.5 \%$ in the future, then 0.5170 probability that the return will be in the interval $[-0.5 \%, 0.5 \%]$, and finally 0.2339 probability that the return will be higher than $0.5 \%$. After the same analysis was carried out with all other companies, we got the results presented in the table below (Table 3).

Table 3: Probability distribution vector in the first next period and the ergodic state vector for each company

\begin{tabular}{|c|c|c|c|c|}
\hline Share & Vector & $\overline{S_{1}}$ & $S_{2}$ & $S_{3}$ \\
\hline \multirow[t]{2}{*}{ NIS } & $s(1)$ & 0.2500 & 0.5159 & 0.2341 \\
\hline & $S^{*}$ & 0.2491 & 0.5170 & 0.2339 \\
\hline \multirow[t]{2}{*}{ FITO } & $s(1)$ & 0.1587 & 0.6151 & 0.2262 \\
\hline & $S^{*}$ & 0.1592 & 0.6141 & 0.2267 \\
\hline \multirow[t]{2}{*}{ GMON } & $s(1)$ & 0.1032 & 0.7897 & 0.1071 \\
\hline & $S^{*}$ & 0.1029 & 0.7894 & 0.1077 \\
\hline \multirow[t]{2}{*}{ AERO } & $s(1)$ & 0.3214 & 0.3532 & 0.3254 \\
\hline & $S^{*}$ & 0.3214 & 0.3532 & 0.3254 \\
\hline \multirow[t]{2}{*}{ KMBN } & $s(1)$ & 0.2540 & 0.5833 & 0.1627 \\
\hline & $S^{*}$ & 0.2537 & 0.5850 & 0.1614 \\
\hline \multirow[t]{2}{*}{ VZAS } & $s(1)$ & 0.1071 & 0.8135 & 0.0794 \\
\hline & $S^{*}$ & 0.1066 & 0.8157 & 0.0777 \\
\hline \multirow[t]{2}{*}{ IMLK } & $s(1)$ & 0.1389 & 0.7540 & 0.1071 \\
\hline & $S^{*}$ & 0.1381 & 0.7552 & 0.1068 \\
\hline \multirow[t]{2}{*}{ IMPL } & $s(1)$ & 0.1111 & 0.7857 & 0.1032 \\
\hline & $S^{*}$ & 0.1111 & 0.7857 & 0.1032 \\
\hline \multirow[t]{2}{*}{ BMBI } & $s(1)$ & 0.0516 & 0.9206 & 0.0278 \\
\hline & $S^{*}$ & 0.0516 & 0.9206 & 0.0278 \\
\hline \multirow[t]{2}{*}{ MTLC } & $s(1)$ & 0.1310 & 0.7341 & 0.1349 \\
\hline & $S^{*}$ & 0.1310 & 0.7341 & 0.1349 \\
\hline
\end{tabular}


Now, if we analyze these results, we can select 4 out of 10 companies with which there is a higher probability that the return will be in $\boldsymbol{S}_{3}$ state than in $\boldsymbol{S}_{\boldsymbol{1}}$ state. These are the following companies: FITO, GMON, AERO and MTLC. Therefore, we can state that, by applying the Markov chains metodology, we obtain an optimal portfolio that includes the companies: FITO, GMON, AERO and MTLC

In Picture 3, we can see the distribution of the ergodic vector $\boldsymbol{S}^{*}$ for states $\boldsymbol{S}_{\boldsymbol{I}}$ and $\boldsymbol{S}_{3}$ for all considered companies. Afore mentioned companies (FITO, GMON, AERO and MTLC) have higher probability returns in $S_{3}$ state than in $\mathrm{S}_{1}$ state. According to the predictions obtained by means of Markov chains this could be very important and interesting to potential investors when making decisions where to invest. It goes without saying that it is better to invest in those shares whose return on investment is higher than $0.5 \%$ than in those whose return is lower than $-0.5 \%$.

Picture 3: Diagram of ergodic state vectors for each company (state $S_{2}$ excluded)

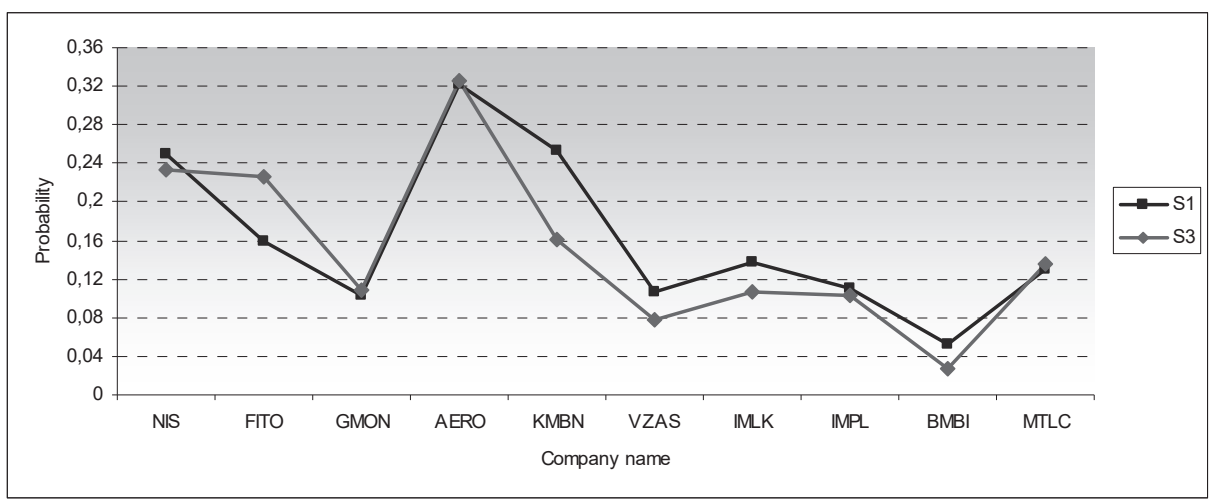

Source: Author

The only thing we have to bear in mind is that this methodology does not consider the issue of risk which is something that always exists when it comes to investing - a theme all investors are well aware of. However, many econometric methodologies that consider both return and risk (as well as other parametres) are much more complicating, demanding and time-consuming and still their results do not differ significantly from those obtained by the Markov chain method.

\section{Conclusion}

This paper is the first one to apply the Markov chains method to the Belgrade stock exchange in studying the expected return on a share. Besides its empirical use, we have also explained the theoretic aspects of this method. All things considered, this method is very simple, understandable and relatively fast compared to some other more complex methods. The data we obtained can be interesting to potential investors as they provide assistance and may serve as guidelines when making decisions with 
regard to what company to invest in, or what shares to include in theirs portfolio. Still, these results are forecasts and not the scientific facts; they show the probability of expected return under the given conditions. We have to bear in mind that the matrix of transition probabilities is constant over time, which is hard to obtain in practice. However, it makes us wonder whether it may be possible to expect greater variance from the concrete results with the prolonged time for observation.

Besides its weaknesses in comparison to some other econometric methods involving distribution of various parameters, we can conclude that a Markov chain as a non-parametric method is significant as it can offer preliminary results regarding expected return. Investors may obtain the information about return in the stock market at least for a short period of time.

Therefore, this paper can be practically used by future investors trading in the Belgrade stock exchange and generally in our still undeveloped capital market which will probably become more turbulent in the future.

\section{References}

Agwuegbo, S. O. N., Adewole, A. P., \& Maduegbuna, A.N. (2010). A Random Walk Model for Stock Market Prices. Journal of Mathematics and Statistics, 6(3), 342-346.

Barnett, A. R., Ziegler, R. M., \& Byleen, E.K. (2006). Applied mathematics for business, economics, life sciences and social sciences. Zagreb: Mate ltd.

Basharin, G. P., Langville, A. N., \& Naumov, V. A. (2004). The Life and Work of A. A. Markov. Linear Algebra and its Applications, Volume 386, 3-26.

Божиновић, М., \& Стојановић, В. (2005). Математичке методе и модели у економији предузећа. Лепосавић: Виша економска школа.

Божиновић, М. (2012). Операциона истраживања. Косовска Митровица: Економски факултет.

BELEX (31.12.2014). Преузето са сајта: http://www.belex.rs/o_berzi/istorijat.

Von Hilgers, P., \& Langville, N. A. (2006). The five greatest applications of Markov chains. Proceedings of the Markov Anniversary Meeting (стр. 155-158). Boson Press.

Doubleday, K.J., \& Esunge, J. N. (2011). Application of Markov Chains to Stock Trends. Journal of mathematics and Statistics, 7(2), 103-106.

McQueen, G., \& Thorley, S. (1991). Are Stock Returns Predictable? A Test Using Markov Chains. The Journal of Finance, 46(1), 239-263.

Svoboda, M., \& Lukáš, L. (2012). Application of Markov Chain analysis to trend prediction of stock indices. Proceedings of 30th International Conference Mathematical Methods in Economics (pp. 848-853.). Karviná: Slezská Univerzita. 
32 Нина Петковић, Милан Божиновић, Сања Стојановић

Шкрињарић, Т., \& Којић, В. (2014). Моделирање приноса дионица на Загребачкој бурзи помоћу Марковљевих ланаца. Економски преглед, 65 (3), 207-221.

Шкрињарић, Т., \& Шостарић, Н. (2014). Комплементарност методологије Марковљевих ланаца и Markowitceva модела оптимизације портфеља. Економска мисао и пракса. 23(1), 353-370.

\section{Summary}

One of the main problems in today's economy is 'conquering the market'or finding the best way to predict price movements and receive expected rates of return. This paper is the first one to apply the Markov chains method to the Belgrade Stock Exchange in studying the expected return on a share. The Markov chains method is chosen as a very simple and non-parametric method which has been insufficiently used and studied in our literature so far. Besides its weaknesses in comparison to some other econometric methods involving distribution of various parameters, this method is significant as it can offer preliminary results regarding expected return. The data obtained in this paper can be interesting to potential investors as they provide assistance and may serve as guidelines when making decisions with regard to what company to invest in. Therefore, this paper can be practically used by future investors trading in the Belgrade stock exchange and generally in our still undeveloped capital market which will probbly become more turbulent in the future. 